\title{
Hazop Study and Fault Tree Analysis for Calculation Safety Integrity Level on Reactor-C.5-01, Oil Refinery Unit at Balikpapan-Indonesia
}

\author{
Silvana R.Dacosta ${ }^{1}$, Al-Asy'ari.I.I. ${ }^{2}$, Ali Musyafa ${ }^{3,{ }^{*}}$ and Adi Soeprijanto ${ }^{4}$ \\ ${ }^{1}$ Department of Electrical Engineering, Faculty of Industrial Technology \\ Kampus ITS, Jl.A.R. Hakim, Surabaya - Indonesia, 60111 \\ ${ }^{2}$ Department of Engineering Physics, Faculty of Industrial Technology \\ Kampus ITS, Jl.A.R. Hakim, Surabaya - Indonesia, 60111 \\ Department of Engineering Physics, Faculty of Industrial Technology \\ Kampus ITS, Jl.A.R. Hakim, Surabaya - Indonesia, 60111 \\ ${ }^{4}$ Professor Department of Electrical Engineering, Faculty of Industrial Technology \\ Kampus ITS, Jl.A.R. Hakim, Surabaya - Indonesia, 60111 \\ ${ }^{*}$ Corresponding author's email: musyafa [AT] ep.its.ac.id
}

\begin{abstract}
A plat former reactors are reactors that are in the plat forming unit is designed for developing your specific hydrocarbon molecules that are used in catalytic engine fuel in boiling point range naphtha and fuel mixture to produce components with a higher octane value. Plat former reactor system failure may disrupt operations in the oil processing refinery unit. These circumstances will cause the supply plaformat as products of the plat forming unit valued high octane which is the main raw material of gasoline blending system is reduced. Resulting in decreased production consequency large losses. The failure of the reactor system can also be harmful to the operator, the environment and there is a possibility of reactor unit may explode. To avoid these risks we conducted studies identify hazards that occur in the process rector Hazard and operability (HAZOP) analysis and calculate the value of safety integrity level (SIL). In this study reviewed three nodes Overview consisting of node stage 1, stage 2 and stage 3. Based on the results of identification are thirteen instruments on the third node, which includes equipment; PC-193, FI-005, PC-194 and FI010. Standards-based Service Oriented systems have Unacceptable risk criteria and the criteria of likelihood 4 Consequences worth three. As for the evaluation of SIL is known that C-5-01 reactor system has two safety Integrity Function (SIS) located in the path of fuel gas and pilot gas lines of the reactor heater. Both SIS has a vote $=1003$ architecture with similar characteristics, and a review of the SIS has a security level SIL $=2$ with a value of PFD = 0.00103 .
\end{abstract}

Keywords- FTA, HAZOP, Reactor, SIL-SIS, Risk.

\section{INTRODUCTION}

In this research has been conducted studies reference explore various sources, including journals, papers, books, and other supporting information. Studies may include studies on Plat forming process unit refinery house V Pertamina Balikpapan, especially plat former reactor[1-2]. The study also includes methods that implemented them on the Fault Three Analysis, HAZOP, and SIL SIS. The reactor is one of the vital elements in the refinery unit. The process is instrumental for separating hydrocarbon bonds heavy petroleum fractions into lighter fractions were carried out with the help of the catalyst granules are processed by heating finely so that it can flow like a liquid fluid. The capacity of the unit is processing 20,000 barrels per day and is able to produce 16.638 barrels platform at $(\mathrm{C} 5+)$ per day, with a minimum octane rating of 96.[3-4] Failure plat former reactor system will interrupt the operation of the oil processing refinery unit. This caused the supply of a product plat form plat forming unit that has a product with a high octane, the product is the main raw material will blended with gasoline will be reduced in number[5-6]

Impact Risk of failure should be minimized, the target company's production will decrease which will result in huge losses. The failure of the reactor system not only can harm humans, the environment and assets and will lead to a reduction in the company's reputation. See the function and role is very critical reactor, the necessary layer of protection 
analysis. All these layers of protection to be important no exception layers of safety integrity level on System Integrity System (SIS). [7-9]

Safety Integrity Level SIS dam should be guaranteed to guarantee that a plant can operate safely. An adequate value SIL is needed to guarantee the reactor system always operates in a sustainable manner. SIS can guarantee the existence of running processes, such as the reactor remains in a safe condition for the installed instrument not only to guarantee Basic Process Control Design, but the reliability of instrument systems also have to meet both in terms of redundancies and in terms of its quality. If a danger arises such as when there is excessive pressure or temperature excess in the reactor, then the system will guaranteed that the components of the instrument that is designed able to overcome the security level either when the system was designed and when operated, SIL according to the standards have been grouped into four levels Safety Integrity Level (SIL). It is expected that the SIL for the Pilot Gas and Gas Flow will be a valuable greater than or equal to two so that the reactor system-level security can be guaranteed[10-12].

\section{MATERIAL AND METHOD}

General overview of the process of mixing naphtha and recycle hydrogen gas at reactor consisting of a combined feed inputs, processes exchanger, output and feedback is shown in Figure 1.

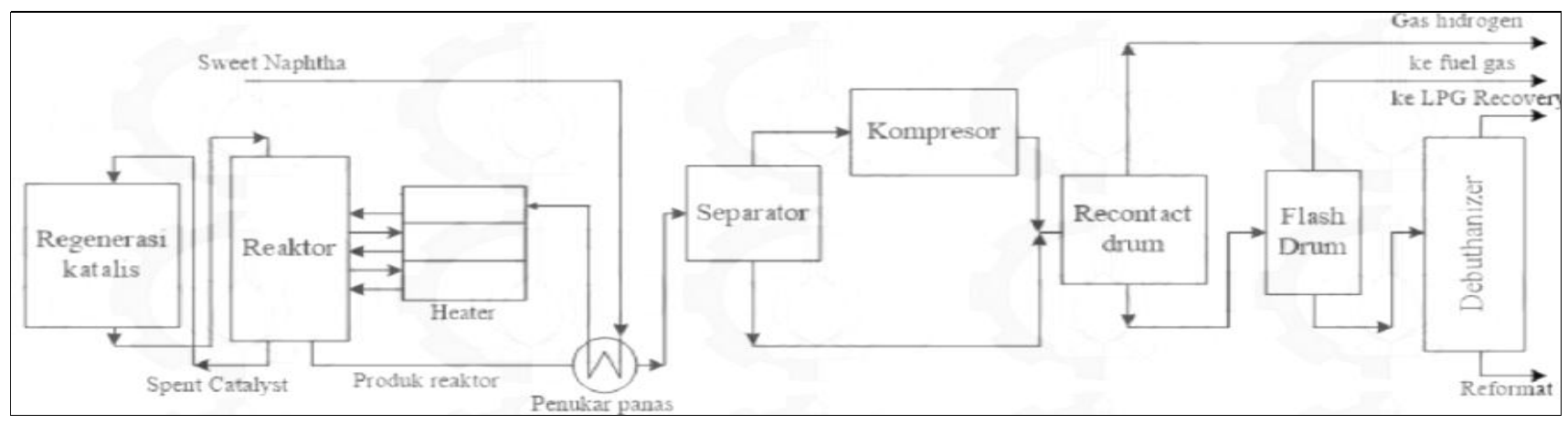

Figure 1: Flow Diagram Plat forming Unit

The data acquired in this study consisted of documents and images Plat forming process unit refinery. Data process in the reactor system C-5-01, A / B / C. Documents process flow diagram (PFD), P \& ID and data maintenance equipment 2010-2015. Data maintenance of the system components of the reactor, the reactor process data for the full month date (1 -30) November 2014. The data sampling once every hour during the day. The data is processed and analyzed to assess the potential hazards, assessed SIL level of each component. Make safety recommendations plat former reactors as standard. The reactor system of Node 1 is shown in Figure 2. [13-15].

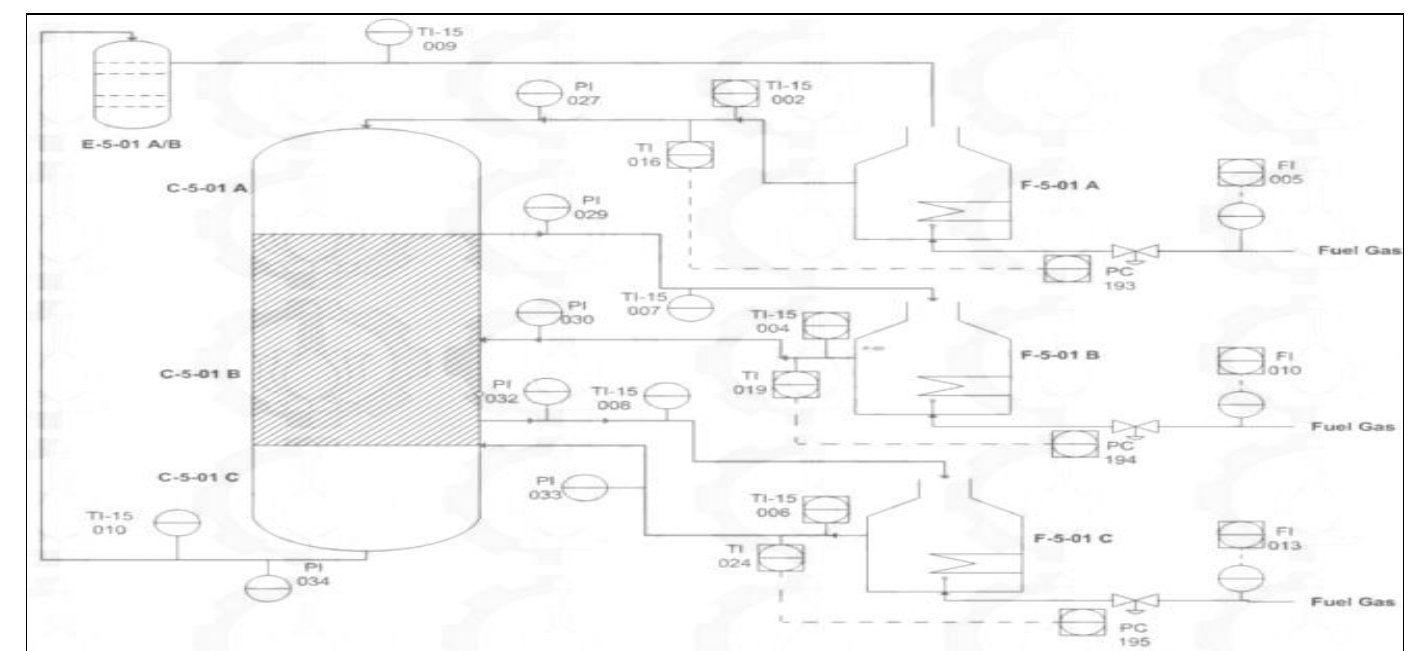

Figure 2: Reactor System as Node-1

Hazard identification starts with knowing the scope of study points (nodes) that are reviewed in the study. It is known that C-5-01 reactor has three stages tasks connected in series as a reactor heater F-5-01 A, F-5-01B and F-5-01C. The reaction process in the reactor has a relatively high temperature. So that the required heating repeated at every step of the 
working reactor. In the document flow sheet description that the control system can be described as follows; Variable operating process occurs in the reactor system and catalyst bed Temperatures chloride / water balance. Temperature is controlled via heaters Catalyst bed reactor, while the balance of water and chloride regulated through the water injection rate and propylene-dichloride. Heaters reactor F-5-01 A / B / C is a heating system that uses gas fuel, so that the continuity of gas supply be the deciding factor on plant fue [14-17].

In the gas heating system pilot lines, early propellant used in the form of natural gas. Referring to the HAZOP studies based on The Concept of Node, and then the flow of processes on the system studied in this research is the reactor C-501. The next stage of this part is divided into two nodes, namely: Node 1, Outlet Combined Feed Exchanger E-5-01A / B to Stage Reactor C-5-01A / B / C via Reactor Heaters F-5-01 A / B / C, and Node 2: Reactor Heaters F-5-01 A / B / C Firing System shown Figure 2. [15-19].

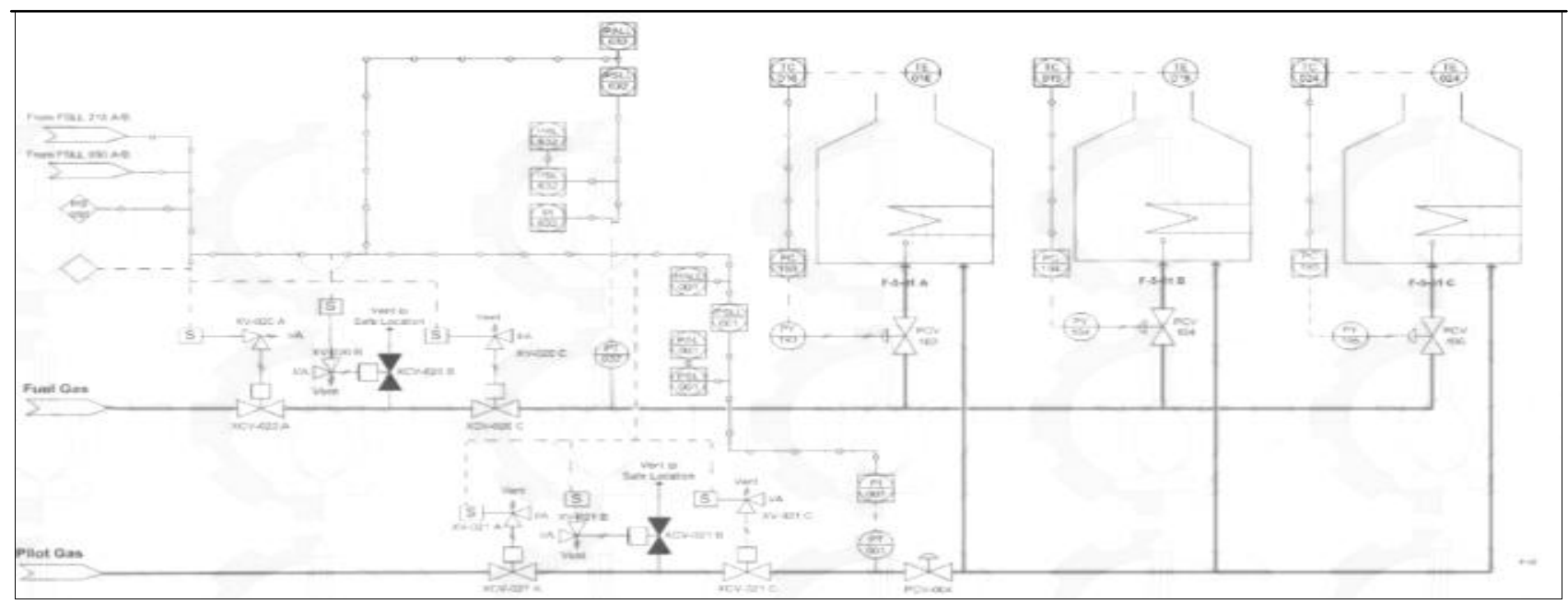

Figure 3: P \& ID System Reactor Node 2

The next stage determines guideword using of process data. The data is processed so that it can be displayed in a chart that accompanied the upper control limit (UCL) and lower control limit (LCL). If the process normally, then the process aberrant activity would seem, especially when there is a process variable out of the upper limit or lower limit. The process will show a deviation that describes the potential dangers of the system. In other parts also reviewed supporting conditions existing security system to see the safeguards that exist on the P\&ID shown in Figure 4. [20-22].

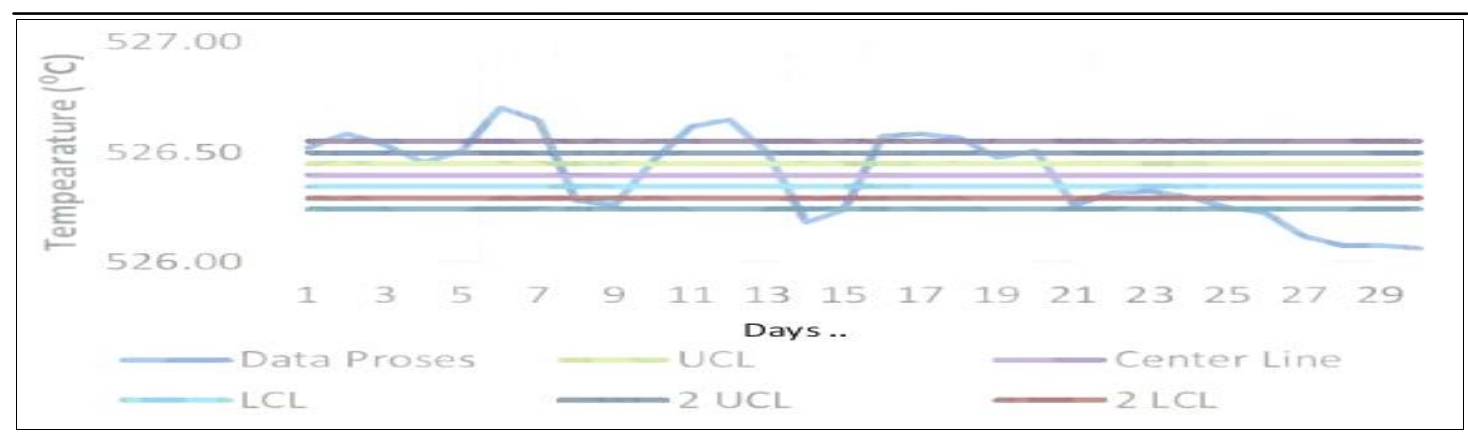

Figure 4: Control Chart for Temperature Process

Risk estimates consist of an analysis of the two reviews, the likelihood and consequences that refers to standard PT. Pertamina. Likelihood is the frequency of the possibility of a risk can occur to a component at a specific time period. In this study, the time period taken for five years (43 800 hours), so that the equations used; Likelihood $=(43800 / \mathrm{MTTF})$, the MTTF values, $\diamond \mathrm{MTTF}=\{1 /$ failure rate $(\lambda)\}$. Consequences qualitatively determined based on how big the losses incurred from the hazards that have been identified. Consequences can be viewed in terms of damage to the components cannot be resumed, in terms of its effect on humans, or in terms of the costs incurred due to the possible danger [23-25].

Risk analysis studied through hazard identification and risk estimation, in this research, risk analysis plat former reactor system using standardized risk matrix by combining the value of likelihood and consequences. SIL analysis through the FTA to use to calculate the value of SIL reactor system, Through modeling FTA, Looking SIS value at each node, and then do a quantitative analysis. The top event is used reactor failure [24-27]. 


\section{ANALISYS AND DISCUSION}

Overview reactor process can be explained that; process in the reactor consists of a naphtha feed to the specifications determined mixture, with the first conducted recycle hydrogen gas before entering the Combined Feed / Exchanger E-5$01 \mathrm{~A} / \mathrm{B}$. This feed has a relatively low termepature and mixed with hydrogen, heated and vaporized before entering the charge heater F-5-01A. Description of the process can be seen in Figure 1. [14-18].

Table 1. Risk Matrix PERTAMINA Standard

\begin{tabular}{c|c|l}
\hline Risk Ranking & Category & \multicolumn{1}{c}{ Description } \\
\hline $1-4$ & A & Acceptable-No risk control measures are needed \\
\hline $5-7$ & C & Acceptable With control -Risk control measures are in place \\
\hline $8-9$ & N & Not Desirable- Risk control measured to introduced within a specified time period \\
\hline $16-20$ & U & Unacceptable \\
\hline
\end{tabular}

Table 2: Safety Integrity Level for SIF

\begin{tabular}{c|c|c}
\hline SIL categories & $\boldsymbol{P F D ~ S I F ~}$ & $\boldsymbol{R R F}=(\mathbf{1 / P F D})$ \\
\hline SIL categories & PFD SIF & RRF $(\mathbf{1 / P F D})$ \\
\hline NR- not requirement & $1 \leq \mathrm{PFD}$ & $\mathrm{RRF} \leq 1$ \\
\hline SIL 0 & $10^{-1} \leq \mathrm{PFD}<1$ & $10^{1}<\mathrm{RRF} \leq 10^{1}$ \\
\hline SIL 1 & $10^{-2} \leq \mathrm{PFD}<10^{-1}$ & $10^{2}<\mathrm{RRF} \leq 10^{3}$ \\
\hline SIL 2 & $10^{-3} \leq \mathrm{PFD}<10^{-2}$ & $10^{3}<\mathrm{RRF} \leq 10^{4}$ \\
\hline SIL 3 & $10^{-4} \leq \mathrm{PFD}<10^{-3}$ & $10^{4}<\mathrm{RRF} \leq 10^{5}$
\end{tabular}

Source: ISA TR 84.00.02-2002

Risk analysis on node- 1 occurs when the heating process naphtha wherein the reaction temperature inside the reactor, can be achieved, so that the temperature is a variable that must be considered intersting prose. In node- 1 also contained process variable, but the variable is not significant. From Figure 2 can be observed that there are seven temperature instruments; IT-15002, TI-15007, TI-15009, TI-15004, TI-15008, IT-15006 and IT-15010.

Table 3. : Guide Word and Deviation Component Node 2

\begin{tabular}{c|l|l|l}
\hline N0. & \multicolumn{1}{|c|}{ Component } & \multicolumn{1}{c}{ Guideword } & \multicolumn{1}{c}{ Deviation } \\
\hline 1. & Temperature Indicator (TI-15002) & More & High Temperature \\
\cline { 3 - 4 } & & Less & Low Temperature \\
\hline 2. & Temperature Indicator (TI-15007) & More & High Temperature \\
\cline { 3 - 4 } & & Less & Low Temperature \\
\hline 3. & Temperature Indicator (TI-15009) & More & High Temperature \\
\cline { 3 - 4 } & & Less & Low Temperature \\
\hline 4. & Temperature Indicator (TI-15004) & More & High Temperature \\
\cline { 3 - 4 } & & Less & Low Temperature \\
\hline 5. & Temperature Indicator (TI-15008) & More & High Temperature \\
\cline { 3 - 4 } & & Less & Low Temperature \\
\hline 6. & Temperature Indicator (TI-15006) & More & Low Temperature \\
\cline { 3 - 4 } & & Less & High Temperature \\
\hline 7. & Temperature Indicator (TI-15010) & More & Low Temperature \\
\cline { 3 - 4 } & & Less &
\end{tabular}

Risk analysis at node 1 , is the result of multiplying likelihood by reference to the risk matrix consequences. Risk analysis node component unit 1 is shown in Table 4. It is known that most of the components on node 1, classified Acceptable risk, there is only one component of which is classified as "Acceptable with Control". Risk Analysis Node-2 is based on a standard risk matrix Pertamina shown by Table -5. It is known there are four components that have the potential Unacceptable Risk namely; PC-193, FI-005, PC-194 and FI-010. Meanwhile, four other components have the potential Not Desirable Risk namely; PC-195, FI-013, PI-632 and PI-001. Evaluation of SIL with the Fault Tree Analysis (FTA) of P \& ID, that on heating the reactor has two SIS, each contained in fuel gas lines and gas pilot lines. After calculating the PFD, in both systems, then the value of SIL can be determined based on the trend graph process data on the components node2, created a table guide word, calculated deviation of each component as shown in Table 5.[17]. 
Table 4: Risk Matrix Component in Node 1

\begin{tabular}{c|c|c|c|c}
\hline \multirow{2}{*}{ No. } & Deviation & \multicolumn{3}{c}{ Risk Score } \\
\cline { 3 - 5 } & High Temperature & 2 & Consequent & Risk Ranking \\
\hline 1. & Low Temperature & 2 & 2 & 4 \\
& High Temperature & 2 & 4 \\
\hline 2. & Low Temperature & 2 & 2 & 4 \\
& High Temperature & 2 & 2 & 4 \\
\hline 3. & Low Temperature & 2 & 2 & 4 \\
\hline 4. & High Temperature & 2 & 2 & 4 \\
& Low Temperature & 2 & 2 & 4 \\
\hline 5. & High Temperature & 2 & 2 & 4 \\
\hline 6. & Low Temperature & 2 & 2 & 4 \\
\hline 7. & High Temperature & 2 & 2 & 4 \\
\hline
\end{tabular}

Table 5: Guide Word and Deviation Component in Node 2

\begin{tabular}{c|l|l|l}
\hline No. & \multicolumn{1}{|c|}{ Component } & \multicolumn{1}{|c}{ Geviation } \\
\hline 1. & Pressure Control (PC-193) & More & High Pressure \\
\cline { 3 - 4 } & & Less & Low Pressure \\
\hline 2. & Flow Indicator (FI-005) & More & More Flow \\
\cline { 3 - 4 } & & Less & Less Flow \\
\hline 3. & Pressure Control (PC-194) & More & High Pressure \\
\cline { 3 - 4 } & & More & More Flow \\
\cline { 3 - 4 } & Flow Indicator (FI-010) & Less & Less Flow \\
\hline 5. & Pressure Control (PC-195) & More & High Pressure \\
\cline { 3 - 4 } & & Less & Low Pressure \\
\hline 6. & Flow Indicator (FI-013) & More & More Flow \\
\cline { 3 - 4 } & & Less & Less Flow \\
\hline 7. & Pressure Indicator (PI-632) & More & High Pressure \\
\cline { 3 - 4 } & & Less & Low Pressure \\
\hline 8. & Pressure Indicator (PI-001) & More & High Pressure \\
\cline { 3 - 4 } & & Less & Low Pressure \\
\hline
\end{tabular}

Table 6: Risk Matrix of Component node 2

\begin{tabular}{l|l|c|c|c}
\hline \multirow{2}{*}{ No. Deviation } & \multicolumn{3}{c}{ Risk Score } \\
\cline { 3 - 5 } & & Likelihood & Consequent & Risk Ranking \\
\hline \multirow{2}{*}{} & High Pressure & 4 & 3 & 12 \\
\hline 1. & Low Pressure & 3 & 3 & 9 \\
& More Flow & 4 & 3 & 12 \\
\hline 2. & Less Flow & 3 & 3 & 9 \\
& High Pressure & 4 & 3 & 9 \\
\hline 3. & Low Pressure & 3 & 3 & 12 \\
& More Flow & 4 & 3 & 9 \\
\hline 4. & Less Flow & 3 & 3 & 8 \\
& High Pressure & 4 & 2 & 6 \\
\hline 5. & Low Pressure & 3 & 2 & 6 \\
\hline 6. & More Flow & 4 & 2 & 8 \\
\hline 7. & Less Flow & 3 & 2 & 6 \\
\hline
\end{tabular}


In the fuel gas lines are SIS as a protection system for the fuel system. Fuel system implemented on the heating system has been running the pressure flowing into the heater should be kept to maintain the operating temperature. In the document flow sheet described that the fuel gas is supplied to the heating lines of $5.3 \mathrm{Kg} / \mathrm{cm} 2 \mathrm{~g}$ and controlled, the pressure was lowered to $2 \mathrm{Kg} / \mathrm{cm} 2 \mathrm{~g}$ pa. Heating path on each F-5-01 A, B \& C by each control valve. SIS on gas fuel lines can be explained by Figure 4. Figure 5 SIF Based on the SIS on line gas fuel consisting of a pressure transmitter (PT-632) as an element of the sensor, logic solver, DCS, and three valve (XCV-020 A, B \& C as well as solenoid valve (XV-020 A, B \& C) in a single line as the final element. [18-19].

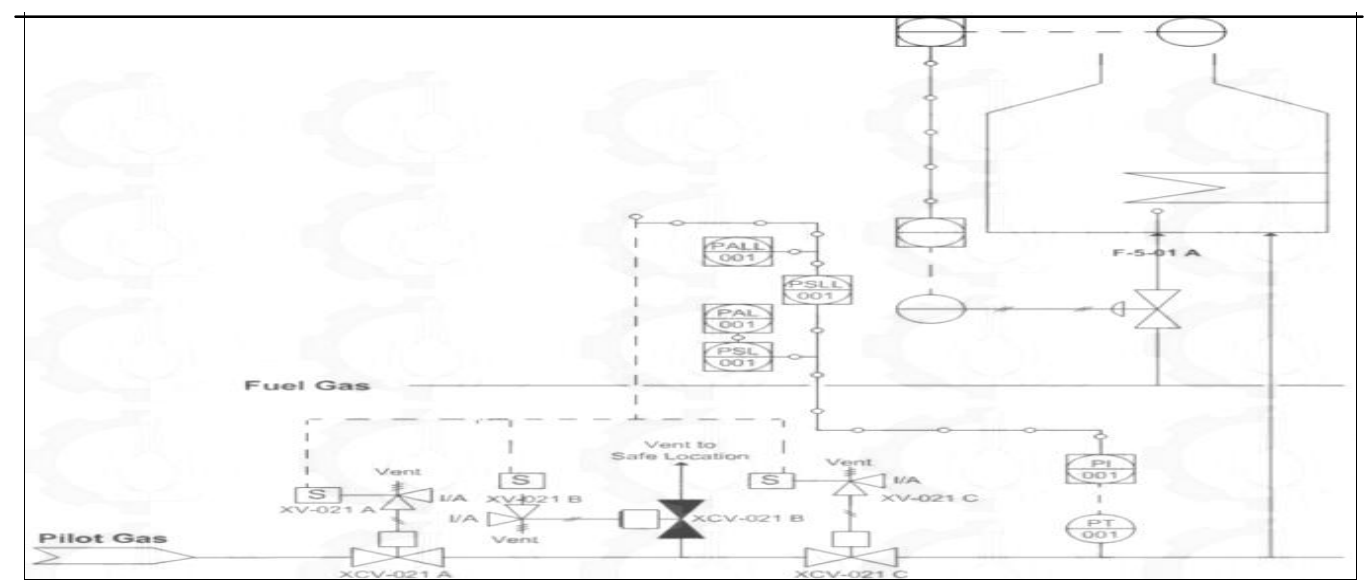

Figure 5: SIS in Fuel Gas

On the track there is a gas pilot SIS as the protection system in the initial combustion heating system heater. Pilot gas supply in the form of natural gas that is given at the start of the heating process with the supply of $3.5 \mathrm{Kg} / \mathrm{cm} 2 \mathrm{~g}$, the pressure should be lowered because of the design pressure of the burners of $0.35 \mathrm{Kg} / \mathrm{cm} 2 \mathrm{~g}$. SIS on track for pilot gas can be seen in Figure 6. Based on the SIF Image of SIS on line gas pilot consists of a pressure transmitter (PT-001) as an element of the sensor, logic solver (DCS), and three valve (XCV $021 \mathrm{~A}, \mathrm{~B} \& \mathrm{C}$ ) and solenoid valve (XV-020 A, B \& C) are in one line as the final element. The value of any component failure rate can be searched generic data reliability, while the value of the test interval (Ti) adjusted with the turnaround time of plant, approximately an average of one year.

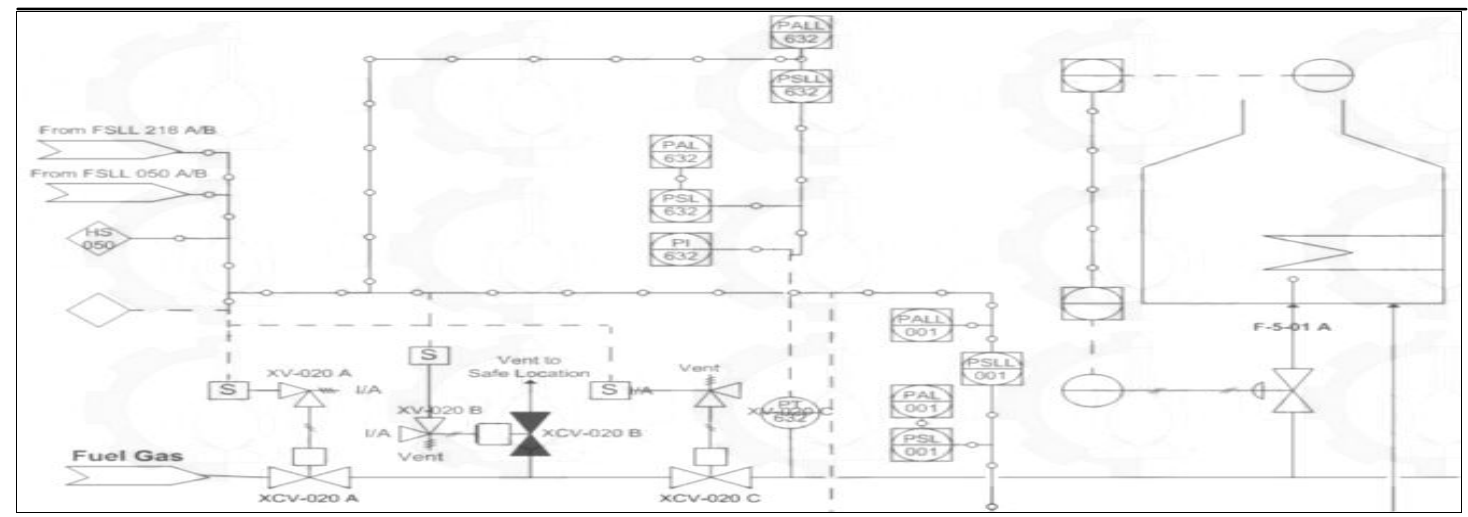

Figure 6: SIS in Pilot Gas

Table 7: Calculation PFD in Fuel Gas System

\begin{tabular}{l|c|c|c}
\hline \multicolumn{1}{c|}{ Component } & Failure rate $\left(\lambda_{\text {DU }}\right)$ & Test Interval $(\boldsymbol{T i})$ & $\boldsymbol{P F D}_{\text {avg }}$ \\
\hline Sensor (PT-632) & 0.01 & 1 year & 0.000004 \\
\hline Logic Solver (DCS) & - & - & 0.000057 \\
\hline Shutdown Valve & 0.020 & 1 year & 0.000032 \\
\hline Solenoid & 0.042 & 1 year & 0.000289 \\
\hline
\end{tabular}




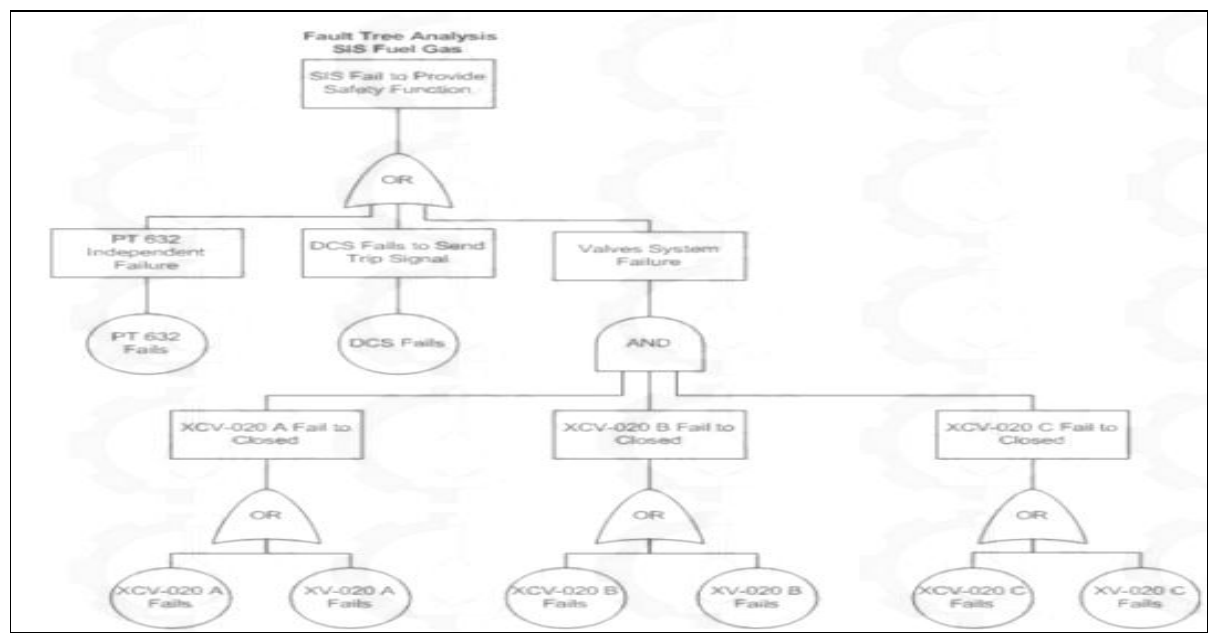

Figure 7: Fault Tree Analysis SIS in System Fuel Gas

- $\quad$ PFD Total $=[\operatorname{PFD}(X C V 020 \mathrm{~A}) \mathrm{U}$ PFD $(\mathrm{XV} 020 \mathrm{~A})] \cap[\mathrm{PFD}(\mathrm{XCV} 020 \mathrm{~B}) \mathrm{U}$ PFD $(\mathrm{XV} 020 \mathrm{~B})] \cap$ [PFD (XCV 020 C) U PFD (XV 020 C)] U [PFD (PT 632) U PFD (DCS)]

- $\quad$ PFD Total $=\{[$ PFD $(X C V 020 \mathrm{~A})+\operatorname{PFD}(\mathrm{XV} 020 \mathrm{~A})] \mathrm{x}[\mathrm{PFD}(\mathrm{XCV} 020 \mathrm{~B})+\mathrm{PFD}(\mathrm{XV} 020 \mathrm{~B})] \mathrm{x}$ [PFD (XCV 020 C) + PFD (XV 020 C)] x [PFD (PT 632) + PFD (DCS)]

- $\quad \mathrm{PFD}$ Total $=\{[0.000032+0.000289421] \times[0.000032+0.0002894] \times[0.000032+0.0002894] \times[0.000004+$ $0.000057\}$

$\mathrm{PFD} \diamond$ Total $=0.001025$, PFD Obtained total of node $1=0.001025$ with the same characteristics and the design of the node 2 has a value of PFD and SIL same. So based on Table Standard SIL known that SIS in the path of fuel gas and pilot gas has SIL 2 criteria.

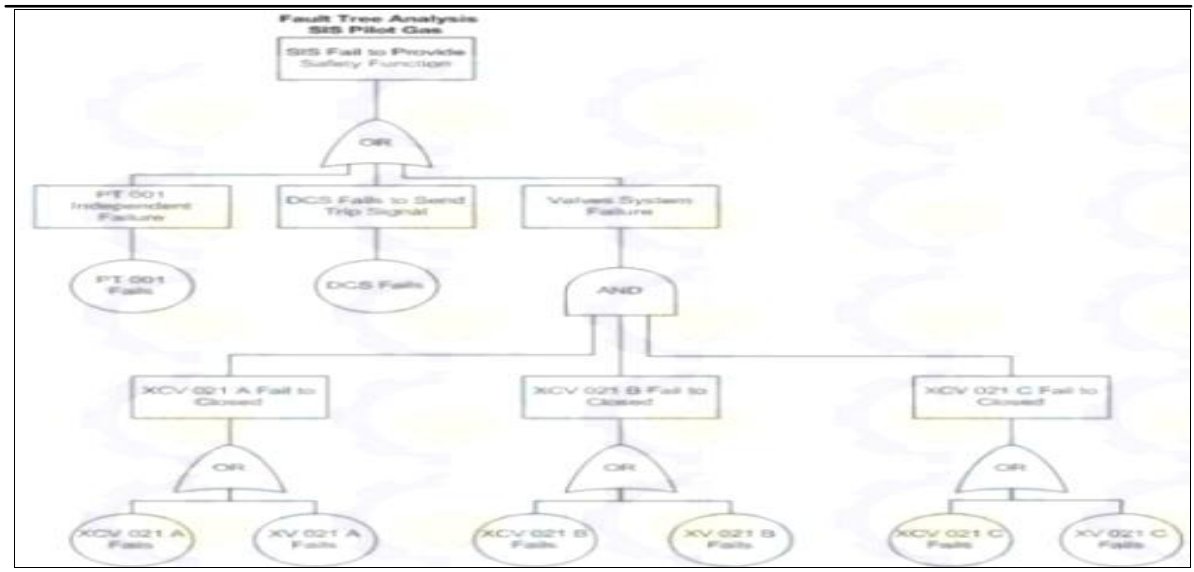

Figure 8: Fault Tree Analysis SIS in Pilot Gas System

Table 8: Calculation of PFD in Pilot Gas System

\begin{tabular}{l|c|c|c}
\hline \multicolumn{1}{c|}{ Component } & Failure rate $\left(\lambda_{\text {DU }}\right)$ & Test Interval $(\boldsymbol{T i})$ & $\boldsymbol{P F D}_{\text {avg }}$ \\
\hline Sensor (PT-001) & 0.010 & 1 year & 0.000004 \\
\hline Logic Solver (DCS) & - & - & 0.000050 \\
\hline Shutdown Valve & 0.020 & 1 year & 0.000032 \\
\hline Solenoid & 0.042 & 1 year & 0.000289 \\
\hline
\end{tabular}

- $\quad$ PFD Total $=[\operatorname{PFD}(X C V 021 \mathrm{~A}) \mathrm{U}$ PFD $(\mathrm{XV} 021 \mathrm{~A})] \cap[\mathrm{PFD}(\mathrm{XCV} 021 \mathrm{~B}) \mathrm{U}$ PFD $(\mathrm{XV} 021 \mathrm{~B})] \cap[\mathrm{PFD}(\mathrm{XCV} 021$ C) U PFD (XV 021 C)] U [PFD(PT 001 ) U PFD (DCS)]

- $\quad \mathrm{PFD}$ Total $=\{[\mathrm{PFD}(\mathrm{XCV} 021 \mathrm{~A})+\mathrm{PFD}(\mathrm{XV} 021 \mathrm{~A})] \mathrm{x}[\mathrm{PFD}(\mathrm{XCV} 021 \mathrm{~B})+\mathrm{PFD}(\mathrm{XV} 021 \mathrm{~B})] \mathrm{x}[\mathrm{PFD}(\mathrm{XCV} 021$ C) + PFD (XV 021 C)] x [PFD(PT 001$)+$ PFD (DCS)]

- $\quad$ PFD Total $=\{[0.000032+0.0002894] \times[0.000032+0.0002894] \times[0.000032+0.0002894] \times[0.000004+$ $0.000057\}$, PFD Total $=0.001025$,

PFD total of node $1=0.001025$ with the same characteristics and the design of the node 2 has a value of PFD and SIL same. Based on Table Standard SIL known that SIS in the path of fuel gas and pilot gas has SIL 2 criteria. 


\section{CONCLUSION}

Based on the study can be conclusion that: From a review third set point, there are four components that have risks and potential dangers of the relatively high; PC-193, PC-194, FI-005 and FI-010. The components are included in the criteria of likelihood $=4$, indicating a failure will occur 3-5 times within a period of five years. Criteria with the consequences $=3$, indicating Injury / Health Impact Moderate. The risk level of risk matrix, it is known that the risk posed of the four components, which are included in the category Unacceptable. And there are four components belonging to the Risk Not Desirable, Acceptable risks with Control total $=1$ fruit and risks classified as Acceptable Risk $=6$ components. To keep the potential hazard does not happen; there should be a recommendation on each rank the risk. Evaluation SIL conducted by the method of FTA, suggesting that the reactor system plat former has a $=2$ pieces SIS which serves as a protection system operational reactor, SIS is first found in the path of fuel gas and SIS both are on track pilot gas to the value PFD nearly equal $=0.001018$, so SIS has a SIL-value $=2$.

\section{ACKNOWLEDGEMENT}

The authors would like to thank the Institute for Research and Community Service (LPPM ITS), Institut Technologi Sepuluh Nopember, Surabaya. With supporting financing the research. Also, the authors would like to thank the anonymous referees for their comments on the eelier version of this work.

\section{REFERENCES}

[1] Arnljot, H., dan Marvin, "System Reliabelity Theory" (John Wiley \& Sons Inc., the Norwegian Institute of Technology, 1994.

[2] AS/NSS, "Australian Standard/New Zealand Standard 4360, "Risk Management", Australian Standard, 1998. [3]

[3] British Standard.," International Electro technical Commission (IEC) 61511-3”, England. British Standard Institution, 2003.

[4] Center for Chemical Process Safety (CCPS), Guidelines for Evaluating Process Plant Buildings for External Explosions Fires and Toxic Releases. America: A John Wiley \& Sons, Inc., 2012.

[5] Dillon, B.S., "Reliability, Quality, and Safety for Engineers" London: CRC Press, 2005.

[6] Ebeling, Charles E.,"An Introduction to Reliability and Maintainability Engineering”, the McGraw-Hill Companies, Inc, Singapore, 1997.

[7] Fletcher, Lyn E., "Potential Explosive Hazards from Hydrogen Sulfide Production in Ship Ballast and Sewage Tanks", Aeronautical and Maritime Research Laboratory, Australia. 1998.

[8] Gruhn, Paul, Harry Cheddar, "Safety Instrumented System Verification: Practical Probabilistic Calculations". United State of America: ISA, 2005.

[9] Jeerawongsuntorn. at.al. "Integration of Safety Instrumented System with Automated HAZOP Analysis: An Application for continuous biodiesel production.” Science Direct. Pp. 412-419, 2011.

[10] Jin Jianghong, at.al, "Quantitative assessment of probability of failing safely for safety instrumented system using Reliability block diagram method", Annals of Nuclear Energy 77 (2015) 30 - 34. 2015.

[11] John N. Dyer, Anya P. Raibagkar, Massimiliano Kolbe, and Ernesto Solano "Blast Damage Considerations for Horizontal Pressure Vessel and Potential for Domino Effects", the Italian Association of Chemical Engineering, Italy, 2012.

[12] Montgomery, Douglas C "Introduction to statistical Quality Control 6 ${ }^{\text {th }}$ Edition", United States of America. 2009.

[13] M. Marshal, Edward and W. Scarp, Eric, "Safety Integrity Level Selection." (United State of America: Research Triangle Park, NC: ISA., 2002.

[14] Musyafa, A. And Kristianingsih, L., "Risk Management and Safety System Assessment from Power Plant Steam Boiler in Power Systems Unit 5, Paiton Indonesia", Australian Journal of Basic and Applied Sciences, 7(11) Sep 2013, Pages: 349-356, 2013.

[15] Musyafa, A. And Zulfiana, Erna., "Risk Management and Hazard and Operability Study on Steam Turbine Power Plant Unit 5 in The Power Generation Paiton, East Java-Indonesia", Advances in Natural and Applied Sciences, 7(5) December 2013, Pages: 510-518, 2013.

[16] Musyafa,A., at.al., " Hazad And Operability Study and Analysis of Safety Integrity Level Case Study: Ammonia Refrigerant Compressor at Petrocemical Plant" Advances in Natural and Applied Sciences, 9(8) July 2015, Pages: 36-42, AENSI Journals, 2015.

[17] Mustafa, A., at.al. "Reliability and Maintainability Assessment of the Steam Turbine Instrumentation System for optimization Operational Availability System at Fertilizer Plant", Australian Journal of Basic and Applied Sciences, 8(13) August 2014, Pages: 132-139, 2014.

[18]. Musyafa, A. et.al., "Evaluation of the Reliability and Prediction Maintenance on the Air Compressor System in Ammonia Plant PT. Petrokimia Gresik", Australian Journal of Basic and Applied Sciences, 9(11) May 2015, Pages: 853-862, 2015.

[19] Poulose, Smear Maria, and Madhu, G., "Hazop Study for Process Plants: A Generalized Approach", International Journal of Emerging Technology and Advanced Engineering, 2012 
[20] Rashid Quiche. Ali A.J Adham.” Reliability of Risk Assessment in petrochemical industries. International Journal of Industrial Management (IJM)". ISSN (Print) 22899286e-ISSN xxxx. Volume xx. Pp pp xx-xxJune, 2015. Universities Malaysia Pahang, Malaysia, 2015.

[21] Robert W. Johnson. "Beyond-compliance uses of HAZOP/LOPA studies”. Science Direct. Pp. 727-733., 2010.

[22] Ronny D. Noriyati, et.al..." Reliability Assessment of Cooling Pump For Parts Inventory Planning in Power Plant System, Paiton-Indonesia”. Australian Journal of Basic and Applied Sciences, 8(13) August 2014, Pages: 140-146 AENSI ISSN:1991-8178. Journal home page: www.ajbasweb.com , 2014.

[23] Silvana D. Costa. et. al. "Evaluation Safety Integrity Level Using Layer of Protection Analysis in Recycle Gas First Stage Cycle Compressor at PT. Pertamina Persero" ., Australian Journal of Basic and Applied Sciences, 9(20) June 2015, Pages: 154-163, 2015.

[24] Skrtic, Lana, "Hydrogen Sulfide, Oil and Gas, and People's Health", Energy and Resources Group University of California, Berkeley. 2006.

[25]. summers, Angela. "Safety Integrity Level: Do You Understand The Odds?” (Journal of Control Engineering, SISTECH solution, LLC, 2000.

[26]. Temilade Ladokun, Farhad , “Accidents in Pressure Vessels: Hazard Awareness", World Congress on Engineering, U.K. ,2010.

[27]. The Norwegian oil industry association, OLF Recommended Guidelines for the application of IEC 61508 and IEC 61511 in the petroleum activities on the Norwegian Continental Shelf, No.: 070 Date effective: 1.0 2, .2001.

ANNEX-1; Worksheet HAZOP Node - 1

\begin{tabular}{|c|c|c|c|c|c|c|}
\hline \multicolumn{6}{|c|}{$\begin{array}{l}\text { Node 1. Outlet Combined Feed Exanger E-501 A/B to Stage Reactor C-5-01 F-5-01 } \\
\text { A/B/C A/B/C via Reactor }\end{array}$} & Drawing : 2 \\
\hline \multicolumn{7}{|c|}{ 1.1 High Temperature } \\
\hline \multirow{2}{*}{ Cause } & \multirow{2}{*}{ Consequences } & \multirow{2}{*}{ Safeguard } & \multicolumn{3}{|c|}{ Risk Score } & \multirow{2}{*}{ Recommendation } \\
\hline & & & $\mathrm{L}$ & $\mathrm{C}$ & RR & \\
\hline \multirow{3}{*}{$\begin{array}{l}\text { 1. The task } \\
\text { overload on } \\
\text { reactor } \\
\text { heater F-5- } \\
01 \mathrm{~A} / \mathrm{B} / \mathrm{C}\end{array}$} & $\begin{array}{l}\text { 1. Cracks excess reacator wall } \\
\text { heater F-5-01 A / B / C } \\
\text { causes the reaction to be } \\
\text { incorrect }\end{array}$ & $\begin{array}{l}\text { 1.TI-016/019/024 } \\
\text { 2.TI-1502/ 15004/ } \\
15006\end{array}$ & 2 & 2 & 4 & 1. Safeguards are sufficient \\
\hline & $\begin{array}{l}\text { 2. Excessive heat causes } \\
\text { damage to the reactor } \\
\text { material heaters F-5-01 A / B } \\
\text { / C }\end{array}$ & $\begin{array}{l}\text { 1. TI } 15001 / 15003 / \\
15003\end{array}$ & 3 & 2 & 6 & 1. Safeguards are sufficient \\
\hline & $\begin{array}{l}\text { 3.Run away to the reactor } \\
\text { heater F-5-01 A / B / C }\end{array}$ & $\begin{array}{l}\text { 1.TI016/019/024 } \\
\text { 2. TI-1502/ 15004/ } \\
15006\end{array}$ & 2 & 2 & 4 & 1. Safeguards are sufficient \\
\hline \multicolumn{7}{|c|}{ 1.2. Low Temperature } \\
\hline \multicolumn{7}{|c|}{ Low Temperature } \\
\hline $\begin{array}{l}\text { 1. The low input } \\
\text { temperature }\end{array}$ & $\begin{array}{l}\text { 1. Duties and reactor material } \\
\text { consumption heater F-5-01 A } \\
\text { / } \mathrm{B} / \mathrm{C} \text { increased and led to a } \\
\text { reduction and termination of } \\
\text { proceedings }\end{array}$ & $\begin{array}{l}1 . \mathrm{TI}-15007 / 15008 / \\
15009\end{array}$ & 2 & 2 & 4 & 1. Safeguards are sufficient \\
\hline $\begin{array}{l}\text { 1. Reactor } \\
\text { heater F-5- } \\
01-\mathrm{A} / \mathrm{B} / \mathrm{C} \\
\text { trip. }\end{array}$ & $\begin{array}{l}\text { 1. Operating conditions is not } \\
\text { reached that cause the } \\
\text { reaction process does not run } \\
\text { correctly }\end{array}$ & $\begin{array}{l}\text { 1. TI-016/019/024 } \\
\text { 2. PCV-193/194/ } 195\end{array}$ & 2 & 2 & 4 & $\begin{array}{l}\text { 1. Safeguards are sufficient } \\
\text { 2. Carry out routine } \\
\text { maintenance PCV193 } \\
\text { SOP / 194/195 }\end{array}$ \\
\hline $\begin{array}{l}\text { 3. Reactor } \\
\text { Work } \\
\text { heaters F-5- } \\
01 \mathrm{~A} / \mathrm{B} / \mathrm{C} \\
\text { is too low }\end{array}$ & $\begin{array}{l}\text { 1. Operating conditions is not } \\
\text { reached that cause the } \\
\text { reaction process does not run } \\
\text { correctly }\end{array}$ & $\begin{array}{l}\text { 1.TI-016/019/024 } \\
\text { 2. TI-15002/15004/ } \\
15006 \\
\text { 3. PCV-193/194/195 }\end{array}$ & 2 & 2 & 4 & $\begin{array}{l}\text { 1. Safeguards are sufficient } \\
\text { 2. Carry out routine } \\
\text { maintenance PCV193 } \\
\text { SOP / 194/195 }\end{array}$ \\
\hline
\end{tabular}


ANNEX-2; Worksheet HAZOP Node - 2

\begin{tabular}{|c|c|c|c|c|c|c|}
\hline \multicolumn{6}{|c|}{ Node 2 Reactor Heaters F-5-01 Firing System } & Drawing : 3 \\
\hline \multicolumn{7}{|c|}{ 1.1. More Flow Fuel Gas } \\
\hline \multirow{2}{*}{ Cause } & \multirow{2}{*}{ Consequences } & \multirow{2}{*}{ Safeguard } & \multicolumn{3}{|c|}{ Risk Score } & \multirow{2}{*}{ Recommendation } \\
\hline & & & $\mathrm{L}$ & $\mathrm{C}$ & RR & \\
\hline \multirow[t]{2}{*}{$\begin{array}{l}\text { 1. The PCV- } \\
\text { 193/194/195, } \\
\text { cannot close } \\
\text { (Stuck } \\
\text { opened) }\end{array}$} & $\begin{array}{l}\text { 1. F-5-01 temperature } \\
\text { increases considerably and } \\
\text { lead to decreased catalyst } \\
\text { lifetime and quality, and } \\
\text { potentially damage the } \\
\text { reactor tube }\end{array}$ & $\begin{array}{l}\text { 1. TI-016/019/024 } \\
\text { 2. TI- } \\
\text { 1502/15004/15006 } \\
\text { 3. PCV-193/194/195 }\end{array}$ & 3 & 3 & 9 & $\begin{array}{ll}\text { 1. } & \text { Safeguard Replace gate } \\
\text { valve after PCV. } \\
\text { 2. } \\
\text { Carry out re-calibration } \\
\text { and routine } \\
\text { maintenance SOP PCV } \\
\text { 193/194/195 }\end{array}$ \\
\hline & $\begin{array}{l}\text { 2. Overheating of the heating } \\
\text { tube causes the hot spots or } \\
\text { material explosion on the } \\
\text { tube. }\end{array}$ & $\begin{array}{l}\text { 1.FI-005/010/013 } \\
\text { 2.TI- } \\
\text { 5001/15003/15005 } \\
\text { 3.PCV-193/194/195 }\end{array}$ & 4 & 3 & 12 & $\begin{array}{l}\text { 1. Safeguard Replace gate } \\
\text { vale after PCV- } \\
193 / 194 / 195\end{array}$ \\
\hline \multirow[t]{2}{*}{\begin{tabular}{|l} 
2. . By Pass \\
PCV- \\
193/194/195 \\
Open / \\
passing
\end{tabular}} & $\begin{array}{l}\text { 1. F-5-01 Temperature } \\
\text { increases cause decreased } \\
\text { catalyst lifetime and quality, } \\
\text { process quality decreases, } \\
\text { potentially damaging the } \\
\text { reactor tube heaters. }\end{array}$ & $\begin{array}{l}\text { 1.FI-005/010/013 } \\
\text { 2.CV-193/194/195 }\end{array}$ & 3 & 3 & 9 & $\begin{array}{l}\text { 1. Safeguards are sufficient } \\
\text { 2. Carry out routine } \\
\text { maintenance on the SOP } \\
\text { PCV 193/194/195 }\end{array}$ \\
\hline & $\begin{array}{l}\text { 2. Overheating of the heating } \\
\text { tube hot spots or even cause } \\
\text { explosions on the tube. }\end{array}$ & $\begin{array}{l}\text { 1.TI-016/019/024 } \\
\text { 2.TI-15001/15003/ } \\
15005 \\
\text { 3.PCV-193/194/195 }\end{array}$ & 4 & 3 & 12 & $\begin{array}{l}\text { 1. Safeguards are sufficient } \\
\text { 2.Carry out routine } \\
\text { maintenance on the SOP } \\
\text { PCV 193/194/195 }\end{array}$ \\
\hline \multirow[t]{2}{*}{$\begin{array}{l}\text { 3. PCV- } \\
\text { 193/194/195 } \\
\text { open due to } \\
\text { weak output } \\
\text { signal }\end{array}$} & $\begin{array}{l}\text { 1. F-5-01 temperature } \\
\text { increases considerably and } \\
\text { lead to decreased catalyst } \\
\text { lifetime and quality. Decrise } \\
\text { process, potentially } \\
\text { damaging the reactor tube } \\
\text { heaters. }\end{array}$ & $\begin{array}{l}\text { 1.FI-005/010/013 } \\
\text { 2.Ti-016/019/024 }\end{array}$ & 3 & 3 & 9 & $\begin{array}{l}\text { 1 Safeguar install the gate, } \\
\text { value after PCV- } \\
\text { 193/194/15 } \\
\text { 2. SOP performs routine } \\
\text { maintenance and checks } \\
\text { on the control loop. }\end{array}$ \\
\hline & $\begin{array}{l}\text { 2. Overheating of the heating } \\
\text { tube causes the hot spots or } \\
\text { even blowup on the tube }\end{array}$ & 1.FI-005/010/013 & 4 & 3 & 12 & $\begin{array}{l}\text { 1 Safeguard install the } \\
\text { gate, value after PCV- } \\
\text { 193/194/15 } \\
\text { 2. SOP performs routine } \\
\text { maintenance checks on a } \\
\text { control loop. }\end{array}$ \\
\hline \multicolumn{7}{|c|}{ 1.2. More Flow Pilot Gas } \\
\hline \begin{tabular}{|l|} 
PCV -004.. \\
Mech. failure
\end{tabular} & 1.Not Significant & - & - & - & - & - \\
\hline \multicolumn{7}{|c|}{ 1.3. Less/No Flow Fuel Gas } \\
\hline $\begin{array}{l}\text { 1. Strainer } \\
\text { clogged on } \\
\text { the flow of } \\
\text { fuel gas }\end{array}$ & $\begin{array}{l}\text { 1. F-5-01 temperature } \\
\text { decreases and causes the } \\
\text { operating conditions are not } \\
\text { right and the quality of the } \\
\text { process of decline }\end{array}$ & $\begin{array}{l}\text { 4.FI-005/010/013 } \\
\text { 5.TI-016/019/024 }\end{array}$ & 3 & 2 & 6 & $\begin{array}{l}\text { 1. To check the condition of } \\
\text { the strainer regularly. }\end{array}$ \\
\hline $\begin{array}{l}\text { 2. The flow of } \\
\text { weak } \\
\text { upstream, }\end{array}$ & $\begin{array}{l}\text { 1. F-5-01 temperature decreases } \\
\text { and causes the operating } \\
\text { conditions are not right and } \\
\text { the quality of the process of } \\
\text { decline }\end{array}$ & $\begin{array}{l}\text { 1.FI-005/010/013 } \\
2 . T I-016 / 019 / 024\end{array}$ & 3 & 3 & 9 & 1. Safeguards are sufficient \\
\hline $\begin{array}{l}\text { 3. PCV- } \\
\text { 193/194/195 } \\
\text { fails to open }\end{array}$ & $\begin{array}{l}\text { 1. F-5-01 temperature } \\
\text { decreases and causes the } \\
\text { operating conditions not } \\
\text { right\& process of decline. }\end{array}$ & $\begin{array}{l}\text { 1.FI-005/010/013 } \\
\text { 2.Ti-016/019/024 }\end{array}$ & 3 & 3 & 9 & $\begin{array}{l}\text { 1. PCV recalibration } \\
193 / 194 / 195\end{array}$ \\
\hline
\end{tabular}




\begin{tabular}{|c|c|c|c|c|c|c|c|}
\hline \multicolumn{8}{|c|}{ 1.4 Less/No Flow Pilot Gas } \\
\hline $\begin{array}{l}\text { 1. There is no } \\
\text { input stream }\end{array}$ & \multicolumn{2}{|c|}{$\begin{array}{l}\text { 1. F-5-01 trip due to low } \\
\text { pressure gas supply to the } \\
\text { gas pilot }\end{array}$} & $\begin{array}{l}\text { 1.PAL-001, PALL- } \\
001 \\
\text { 2.XCV-021/A/B }\end{array}$ & 1 & 1 & 1 & 1. Safeguards are sufficient \\
\hline $\begin{array}{l}\text { 2.PCV-004 } \\
\text { Clogged / } \\
\text { deadlocked } \\
\end{array}$ & \multicolumn{2}{|c|}{$\begin{array}{l}\text { 1. The flow of gas pilot } \\
\text { missing }\end{array}$} & 1.PI-001 & 1 & 1 & 1 & - \\
\hline \multicolumn{8}{|c|}{ 1.5 High Pressure Fuel Gas } \\
\hline $\begin{array}{l}\text { 1. High } \\
\text { upstream } \\
\text { pressure }\end{array}$ & \multicolumn{2}{|c|}{ 1.Not Significant } & - & - & - & - & - \\
\hline \multirow[t]{2}{*}{$\begin{array}{l}\text { 2. PCV- } \\
\text { 193/194/195 } \\
\text { cannot close } \\
\text { (stuck } \\
\text { opened) }\end{array}$} & \multicolumn{2}{|c|}{$\begin{array}{l}\text { 1. F-5-01 temperature } \\
\text { increases considerably and } \\
\text { leads to decreased catalyst } \\
\text { lifetime and quality, process } \\
\text { quality decreases, and } \\
\text { potentially damage the } \\
\text { reactor tube heaters. }\end{array}$} & $\begin{array}{l}\text { 1.TI-016/019/024 } \\
\text { 2.PCV-193/194/ } 195\end{array}$ & 3 & 3 & 9 & $\begin{array}{l}\text { 1 Safeguard tide gate, } \\
\text { value after PCV- } \\
\text { 193/194/15 } \\
\text { 2. Perform routine } \\
\text { maintenance on the } \\
\text { SOP PCV 193/194/15 }\end{array}$ \\
\hline & \multicolumn{2}{|c|}{$\begin{array}{l}\text { 2. Overheating of the heating } \\
\text { tube causes the hot spots or } \\
\text { even an explosion on the } \\
\text { tube }\end{array}$} & $\begin{array}{l}\text { 1.TI-016/019/024 } \\
\text { 2.TI- 5001/15003/ } \\
15005 \\
\text { 3. PCV-193/194/ } 195\end{array}$ & 4 & 3 & 12 & $\begin{array}{l}\text { 1 Safeguard tide gate, } \\
\text { value after PCV- } \\
193 / 194 / 15 \\
\text { 2. Perform routine } \\
\text { maintenance on the SOP } \\
\text { PCV 193/194/15 }\end{array}$ \\
\hline \multirow[t]{2}{*}{$\begin{array}{l}\text { 3. By Pass PCV } \\
\text { 193/194/195 } \\
\text { open / } \\
\text { passing }\end{array}$} & \multicolumn{2}{|c|}{$\begin{array}{l}\text { 1. F-5-01 temperature } \\
\text { becomes much and cause } \\
\text { catalyst lifetime and } \\
\text { quality, process decline and } \\
\text { potentially damage the } \\
\text { reactor tube heaters. }\end{array}$} & $\begin{array}{l}\text { 1.TI-016/019/024 } \\
\text { 3.PCV-193/194/ } 195\end{array}$ & 3 & 3 & 9 & $\begin{array}{l}\text { 1. Safeguards are sufficient } \\
\text { 2. Perform routine } \\
\text { maintenance on the SOP } \\
\text { PCV 193/194/15 }\end{array}$ \\
\hline & \multicolumn{2}{|c|}{$\begin{array}{l}\text { 2. overheating of the heating } \\
\text { tube causes the hot spots } \\
\text { explosion on the tube }\end{array}$} & \begin{tabular}{|l} 
1.TI-016/019/024 \\
2.TI-5001/15003/ 15005 \\
3.PCV-193/194/195
\end{tabular} & 4 & 3 & 12 & $\begin{array}{l}\text { 1. Safeguards are sufficient } \\
\text { 2. Perform routine } \\
\text { maintenance on the SOP } \\
\text { PCV 193/194/15 }\end{array}$ \\
\hline \multicolumn{8}{|c|}{ 1.6. High Pressure Pilot Gas } \\
\hline \multicolumn{3}{|c|}{$\begin{array}{l}\text { 1. Mechanical failure } \\
\text { on the PCV-004 }\end{array}$} & - & - & - & - & - \\
\hline \multicolumn{8}{|c|}{ 1.7. Low Pressure Fuel Gas } \\
\hline $\begin{array}{l}\text { 1. Low pressure } \\
\text { upstream }\end{array}$ & \multicolumn{2}{|c|}{$\begin{array}{l}\text { 1. F-5-01 temperature } \\
\text { decreases and causes the } \\
\text { operating conditions are not } \\
\text { right. }\end{array}$} & $\begin{array}{l}\text { 1.TI-016/019/024 } \\
\text { 2.PI-632 (local) } \\
\text { 3.PAL-632,PALL-632 } \\
\text { 4.XCV020,/A/B/C }\end{array}$ & 3 & 3 & 9 & 1. Safeguards are sufficient \\
\hline $\begin{array}{l}\text { 2. } 93 / 194 / 195 \\
\text { PCV- not fail } \\
\text { to close }\end{array}$ & \multicolumn{2}{|c|}{$\begin{array}{l}\text { 1. F-5-01 temperature } \\
\text { decreases and causes the } \\
\text { operating conditions are not } \\
\text { right and the quality of the } \\
\text { process of decline }\end{array}$} & $\begin{array}{l}\text { 1.TI-016/019/024 } \\
\text { 2.PI-632 (local) }\end{array}$ & 3 & 3 & 9 & $\begin{array}{l}\text { 2. Carry out routine } \\
\text { maintenance on the } \\
\text { SOP PCV 193/194/15 }\end{array}$ \\
\hline $\begin{array}{l}\text { 3. Steiner fuel } \\
\text { gas stream } \\
\text { clogged }\end{array}$ & \multicolumn{2}{|c|}{$\begin{array}{l}\text { 1. F-5-01 temperature } \\
\text { decreases and causes the } \\
\text { operating are not correct and } \\
\text { quality process decries. }\end{array}$} & $\begin{array}{l}\text { 1.TI-016/019/024 } \\
\text { 2.PI-632( Local) }\end{array}$ & 3 & 2 & 6 & $\begin{array}{l}\text { 1. Checking the condition } \\
\text { of the strainer regularly }\end{array}$ \\
\hline \multicolumn{8}{|c|}{ 1.8. Low Pressure Pilot Gas } \\
\hline $\begin{array}{l}\text { 1. Low pressure } \\
\text { upstream }\end{array}$ & \multicolumn{2}{|c|}{$\begin{array}{l}\text { 1. Not the flame to the } \\
\text { combustion reactor heaters } \\
\text { F-5-01 }\end{array}$} & $\begin{array}{l}\text { 1.PI-001 } \\
\text { 2.PI-002 (local) } \\
\text { 3.PAL-001,PALL-001 }\end{array}$ & 4 & 2 & 8 & 1. Safeguards are sufficient \\
\hline $\begin{array}{l}\text { 2. Steiner the } \\
\text { pilot gas flow } \\
\text { is clogged } \\
\end{array}$ & \multicolumn{2}{|c|}{$\begin{array}{l}\text { 1. Not the flame to the } \\
\text { combustion reactor heaters } \\
\text { F-5-01 }\end{array}$} & $\begin{array}{l}\text { 1.PI-001 } \\
\text { 2.PI-002 (local) } \\
\text { 3.PAL-001,PALL-001 } \\
\end{array}$ & 4 & 2 & 8 & $\begin{array}{l}\text { 2. Carry out checking and } \\
\text { cleaning strainer before } \\
\text { start up }\end{array}$ \\
\hline
\end{tabular}

